\title{
Sustainability of Inner Mongolian Grasslands: Application of the Savanna Model
}

\author{
LINDSEY CHRISTENSEN ${ }^{1}$, MICHAEL B. COUGHENOUR ${ }^{2}$, JAMES E. ELLIS ${ }^{2,4}$, AND ZUOZHONG CHEN ${ }^{3}$
}

\begin{abstract}
Authors are ${ }^{1}$ Postdoctoral fellow, Center for Environmental Science and Policy, Stanford University, Stanford, Calif. 94305-6055; ${ }^{2}$ Senior Research Scientist, Natural Resource Ecology Laboratory, Colorado State University, Fort Collins, Colo. 80523; ${ }^{3}$ Professor, Ecology Research Center, Institute of Botany, Chinese Academy of Science, Beijing, China 100093; ${ }^{4}$ Deceased. At time of the research, the senior author was Research Assistant, Natural Resource Ecology Laboratory, Colorado State University, Fort Collins, Colo.
\end{abstract}

\begin{abstract}
The sustainability and resilience of an Asian typical steppe grazing ecosystem was assessed by determining thresholds and stable states with an ecosystem simulation model. This analysis used the Savanna model to simulate spatial climate, vegetation, and livestock grazing dynamics, at 14 different stocking rates $\left(5.5-59.8 \mathrm{AUY} \mathrm{km}^{-2}\right)$. Grazing effects on vegetation were assessed, including effects on primary production, vegetation composition, and root biomass. Simulations were run for 100 years: 50 years to examine sustainability and 50 years to examine resilience of the system. Results showed that a grazing intensity $(1-\mathrm{g} / \mathrm{u} ; \mathrm{g}=$ biomass in grazed area, $\mathrm{u}=$ biomass in ungrazed area) of 0.49 was sustainable for this particular system. This region was resilient to grazing up to the intensity of 0.49 , where the system remained dominated by herbaceous production. Grazing intensities higher than $\mathbf{0 . 4 9}$, in combination with low precipitation events, resulted in decreased herbaceous net primary production and root biomass, and increased shrub net primary production and root biomass. Herbaceous vegetation was unable to gain a competitive advantage over shrubs in areas where grazing intensities were above 0.49 ; consequently, the system shifted to a stable shrub-dominated state that could not return its original composition even without further grazing.
\end{abstract}

Key Words: grazing management, modeling, thresholds, sustainability and resilience, typical steppe, Inner Mongolia

The long-term sustainability and resilience of Asian grassland ecosystems may be under threat as a result of changes in grazing management patterns and intensification of land use. In Inner Mongolia, Peoples Republic of China, the predominant land use pattern has shifted, over the last 50-60 years, from one of mobile, extensive range utilization, to sedentary livestock operations, increased stocking rates, and expansion of dryland cultivation.

The authors acknowledge the cooperation and help of the Inner Mongolia Grassland Ecosystem Research Station, Inner Mongolia, China and the Institute of Botany, Chinese Academy of Science. This research was sponsored by grants from the U.S. National Science Foundation, Program for Methods and Models for Integrated Assessment: (grant \#ATM 9979958) Integrated Assessment of ClimateEcosystem Interactions on East Asian Steppes: Implications of climate change and Land Use Intensity. We would like to give most sincere thanks to Dr. James Elliswho gave tremendous support with both the research and writing of this paper but whose untimely death prevented him from seeing the final publication.

Manuscript accepted 11 Sept. 02.

\section{Resumen}

La sustentabilidad y resilencia de un ecosistema de pradera Asiática típica para apacentamiento fue evaluada con modelos de simulación de ecosistemas para determinar los umbrales y los estados estables. Este análisis uso la Savanna para simular la variabilidad espacial del clima, vegetación y dinámicas de apacentamiento con 14 diferentes cargas animal (5.5 - 59.8 UAA $\mathrm{km}^{-2}$ ). Se evaluaron los efectos del apacentamiento sobre la vegetación, incluyendo los efectos sobre la producción primaria, composición de la vegetación y la biomasas de raíces. Las simulaciones se corrieron para 100 años: 50 para examinar la sustentabilidad y 50 para examinar la resilencia del sistema. Los resultados mostraron que a una intensidad de apacentamiento de (1-g/u; $g$ = biomasa en el área apacentada , $u$ = biomasa en el área sin apacentar) 0.49 fue sustentable para este sistema particular. Esta región fue resilente al apacentamiento hasta una intensidad de 0.49 , donde el sistema permanece dominado por la producción herbácea. Intensidades de apacentamiento mayores de 0.49, en combinación con eventos de baja precipitación, resultaron en reducciones de la producción de primaria neta herbácea y biomasa de raíces y aumento la producción primaria neta y biomasa de raíces de los arbustos. La vegetación herbácea fue incapaz de ganar ventaja competitiva sobre los arbustos en áreas donde la intensidad de apacentamiento fue superior a 0.49 ; consecuentemente, el sistema es desviado a un estado estable dominado por arbustos que puede no regresar a su composición original aunque este no se someta mas a apacentamiento.

Results include land degradation in the form of activated sand dunes in heavily degraded regions and altered vegetation structure in other areas (Jianguo and Loucks 1992, Chen and Xiao 1993, Williams 1996a, Renzhong and Ripley 1997, Sneath 1998). These changes in management style and increases in demand for livestock products have contributed to improved economic returns to livestock production in the short run. However, many scientists believe that present exploitation rates are unsustainable in the long run and that major declines in ecosystem production and/or irreversible changes in vegetation state are probable.

Grassland systems are subject to shifts among stable states due to threshold effects in grazing systems (Noy-Meir 1975, Westoby et al. 1989, Friedel 1991). The recent shifts in vegetation and increases in livestock populations on the Asian typical steppe, a bunch-grass steppe with many or few forbs in a semi-arid climate (Lavrenko and Karamysheva 1993, Zhu 1993), demonstrate a 
lack in understanding of grazing management and an urgent need to determine appropriate grazing regimes (National Research Council 1992). Models can be used to understand interactions between abiotic and biotic factors to determine which grazing practices and intensities of use are sustainable and do not lead to degradation (Caughley et al. 1987, Agren et al. 1991, Ellis et al. 1993, Hall and Day 1997). We chose the Savanna ecosystem model (Coughenour 1993) to examine these interactions.

The Savanna model is a spatial and dynamic model that simulates ecosystem processes including vegetation and livestock production. The model takes a process-oriented approach to represent grassland ecosystems including flows of biomass, nitrogen, and organisms, and subsequent changes in system states. The capabilities of the model to simulate interactive responses to grazing can be used to further our understanding of the sustainability and resilience of semi-arid grasslands. Sustainability is defined as the nondegradive use of ecosystems that maintains system health for present and future generations (Lubchenco et al. 1991, Lele and Norgaard 1996) and resilience is defined as the amount of disturbance an ecosystem can experience before it shifts to an alternate state (Holling 1973, Gunderson 2000). Here we used this model to examine plant competition and grazing on the typical steppe of Northern China to determine the implications of different grazing regimes to ecosystem sustainability and resilience.

\section{Methods}

\section{Study area}

This study was focused on the Baiinxile livestock farm, which is located on the typical steppe of Inner Mongolia, China $\left(43.5^{\circ} \mathrm{N}, 116.5^{\circ} \mathrm{E}\right)$. The farm is $3,680 \mathrm{~km}^{2}$, divided into an administrative village and 12 branches. A branch is an administrative division of land, ranging in size from 79 $\mathrm{km}^{2}$ to $655 \mathrm{~km}^{2}$. Herders are sedentary with the majority of their land allocated to grazing. The farm is grazed predominately by a mixture of cattle, sheep, and horses.

Long-term mean annual precipitation at Baiinxile is $360 \mathrm{~mm}$ but varies between $180 \mathrm{~mm}$ and $500 \mathrm{~mm}$. Mean annual temperature is $-0.4^{\circ} \mathrm{C}$, ranging from $-27.0^{\circ} \mathrm{C}$ to $28.6^{\circ} \mathrm{C}$ ( $\mathrm{Li} 1989$, Xiao et al. 1997). The 3 main soil types in this area are kastanozems, chernozems, and eolian sandy soils (FAO 1991). Dominant grasses include Stipa grandis and Leymus chinensis, which have a C3 photosynthetic pathway. Dominant forbs include Artemisia frigida and Potentilla sp., while the primary shrubs are Caragana microphylla and Astragalus melilotoides (Li 1978).

\section{Model description}

The Savanna model (Coughenour 1993) is a spatially explicit, process-oriented model of grassland, shrubland, savanna, and forested ecosystems. The model simulates processes at a landscape through regional spatial scales over annual to decadal time scales. The model is composed of site hydrology, plant biomass production, plant population dynamics, ungulate herbivory, ungulate spatial distribution, ungulate energy balance, and ungulate population dynamics submodels (Fig. 1).

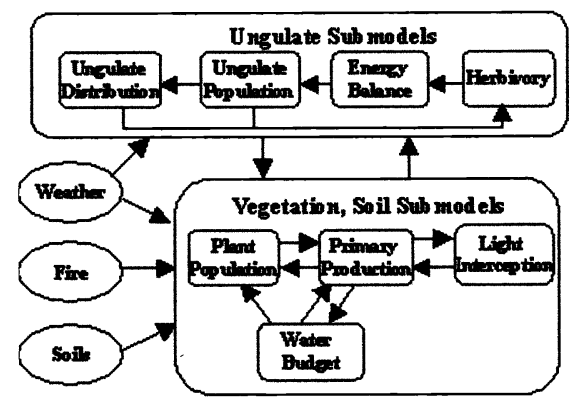

Fig. 1. Savanna model structure (Coughenour 1993).

The Savanna model has a nested spatial structure that is spatially explicit (representing spatial position) at the landscape scale. Grid-cell size is scaled to the spatial extent of the simulated ecosystem. A landscape is covered by grid-cells. The model is spatially inexplicit at sub-grid patch scales. The model represents the proportions of each grid-cell that are covered by vegetation patches or "facets". Patch locations are not modeled, but the model does represent the fractions of ground area covered by patches of herbaceous plants, shrubs, and trees in each grid-cell. Since plant growth is simulated, patch cover is a dynamic outcome of simulated vegetation growth and mortality. The results are scaled-up to the grid-cell level by multiplying the fractions of the grid-cell area covered by each patch type.

Water is redistributed by modeling runoff and runon. By simulating water movements among landscape positions, the model accounts for effects of patch- scale landscape structure on soil water storage and subsequent plant growth. Runon potentially recharges deeper soil layers, thus affecting the balance between deep and shallow rooted plant species, and the length of the period during which water is available to support plant growth.

The Savanna model is driven by monthly weather data. Precipitation data may be from multiple weather stations, or it may simply be comprised of data from a single station. Monthly temperature data from a base station at known elevation are corrected for grid-cell elevations according to temperature lapse rate. A snowmelt submodel simulates snow water content and depth, and snow crusting is stochastically related to temperature.

The water budget submodel simulates soil moisture dynamics and use on each patch type on each grid-cell. Soils map data are used, in conjunction with soil properties for each soil type, to determine soil water holding capacities of each subarea on each grid-cell. The water budget includes terms for precipitation, interception, runoff, runon, infiltration, deep drainage, bare soil evaporation, and transpiration.

The net primary production (NPP) submodel simulates plant biomass dynamics. Plant biomass production is affected by light, water, temperature, nitrogen, and herbivory. The NPP submodel is explicitly linked to the water budget submodel through an empirical relationship between carbon assimilation rate and stomatal conductance (Ball 1988). Biomass is allocated to leaves, stems, and roots. Plant tissues die due to water or temperature stress or phenological state, and they turn over at a nominal rate that reflects their maximal longevities. The NPP submodel also simulates losses due to herbivory and tissue mortality.

Plant population submodels simulate plant establishment, size, and mortality. Plant establishment is affected by herbaceous standing crop, water and temperature. The population models simulate either a single variable-size class or up to 6 fixed-size classes of plants. Mortality occurs at a nominal rate accentuated by water and temperature stress. Competition between plants occurs at the functional group level, based on water, nutrient, and light resources. When demands for soil resources exceed availability, plants acquire the available resources based upon relative demands in each of 3 rooting layers. The plant population submodels are explicitly linked to the NPP model.

Simulated forage biomass and nutrient content are used to predict forage offtake 
and ungulate distribution across the landscape. Forage intake then affects ungulate energy balance, which subsequently affects ungulate population dynamics, which are modeled separately for each type of livestock. Forage offtake is affected by forage quantity and availability, and ungulate diet composition and preference, maximal species intake rates, and stocking rates, which are unique to each ungulate type. Ungulate weight dynamics are derived by modeling herbivore energy intake and expenditure, and resultant changes in body mass. An animal condition index is then calculated, and can be used to affect ungulate population distribution. The Savanna model distributes ungulate populations based on habitat locations of suitable forage and management practices. For this analysis sheep, horses, and cattle per $\mathrm{km}^{2}$ were entered as model input.

The model's structure includes rasterized GIS maps of vegetation, soil, elevation, slope, and aspect for the Baiinxile farm. Spatial analyses and model output are provided at the scale designated by the grid-cell size. A $1-\mathrm{km}^{2}$ grid-cell size was used for this analysis. Management strategies are incorporated into the model by limiting and restricting livestock movements with forcing and boundary maps created in a GIS. The model therefore has the ability to simulate ecosystem responses to alternative livestock management practices involving movements of animals amongst pastures.

The Savanna model has been used to simulate vegetation and ungulates in a wide variety of ecosystems such as Rocky Mountain National Park, Colo. (Weisberg 2000); Yellowstone National Park, Wyo. (Coughenour and Singer 1996a, 1996b); Ngorongoro Conservation Area, Tanzania (Boone et al. 2002); and Kruger National Park, South Africa (Kiker 1998).

\section{Model parameterization/verification}

Fieldwork conducted in Inner Mongolia was used to parameterize the vegetation and soil portions of the model (Xiao et al. 1996, Christensen et al. 1998). Vegetation biomass and percent cover data from lightly grazed plots were used in Savanna initialization parameter files to describe the vegetation at the Bainxile farm (Christensen et al. 1998). The purpose was to use the model to simulate vegetation in a non-disturbed state. Both percent cover and vegetation biomass of each functional group were used in model initialization files. Other plant parameters specific to this region, such as plant physiological
Table 1. Vegetation categories used in Savanna simulation runs, simplified from Xiao et al. (1997).

\begin{tabular}{ll}
\hline \hline & Vegetation classification \\
\hline 1 & meadow steppe \\
2 & typical steppe \\
3 & Artemisia frigida \\
4 & desertificated land \\
5 & saline alkaline land \\
6 & wetland \\
7 & cropland \\
8 & fallow cropland \\
9 & sand dunes with Ulmus sp. \\
\hline
\end{tabular}

characteristics, were taken from several chapters in Yang (1987). The base vegetation map consists of 9 vegetation types (Table 1) modified from a vegetation classification of Landsat TM imagery (Xiao et al. 1997). Biomass data from 1980 to 1989 (Xiao et al. 1996) were used for model verification analysis.

Field soil texture data from soil samples were used to parameterize soil water holding capacity and water infiltration rates. A digitized soil map of China (scale 1:4 million) was used as the soil base vegetation map.

Simulated livestock species included sheep, horses, and cattle, the primary grazers on the livestock farm. Information needed for model parameters such as livestock height, weight, and diet were gathered from livestock data specific to the typical steppe (Yang 1987). Herbaceous plants were selected as the preferred forage type due to the overall dominance of grass and forbs in this ecosystem.

On the typical steppe, areas of grassland are reserved for hay cutting and winter grazing. To reproduce this spatial effect in model simulations, "force maps" were used. Force maps blocked use of specified areas during summer months, and were then removed during winter months to make the areas available. Vegetation cells classified as meadow steppe were blocked from grazing during April through November to simulate areas reserved for fodder growth during the growing season. Grid-cells classified as meadow steppe were chosen because these areas were more productive, higher in elevation, and further away from water holes, and were therefore reserved for fodder growth (personal communication with local herders). Areas classified as sand dunes were reserved for winter grazing because of the shelter they provided against winter climate events.

Climate data from the Inner Mongolia Grassland Ecosystem Research Station (IMGERS), centrally located in the Baiinxile Farm, and 6 surrounding weath- er stations were used in Savanna simulations. Nineteen years of maximum and minimum temperatures, precipitation, wind speed, humidity, and radiation data collected at the station were used in model analyses. Random years were chosen from the original 19 to create a weather data set for 50 years. Precipitation data from 6 surrounding weather stations were used in the weather interpolation submodel of Savanna.

\section{Model validation}

Model validations compared satellite imagery, not used in model parameterization, to final model output to determine model simulation accuracy (Jorgensen 1994). Eleven years, 1982-1992, of Normalized Difference Vegetation Index (NDVI) bimonthly composites derived from satellite imagery (Tucker 1979, Justice et al. 1985, Tucker et al. 1985 , Malingreau 1986), totaling 66 images, were used to validate Savanna simulation output (Christensen et al. 1999). The NDVI data were analyzed in Idrisi (IDRISI 1997). The Idrisi software was used to extract time series of mean NDVI values for each branch of the farm. These trends were plotted and compared to Savanna green vegetation biomass outputs, which were also averaged over cells for each branch. A regression analysis of NDVI data versus simulated model results was used to test the model. The Savanna model green vegetation biomass output included summation of green leaf mass of herbaceous, shrubs, and trees and green herbaceous stem biomass. The 11-year cyclic trend in NDVI compared directly to model output rather than biomass values derived from NDVI. Ideally conversions to biomass would be used, if corrections could be made for errors in the Advanced Very High Resolution Radiometer data arising from satellite orbital drift and volcanic aerosols (Privette et al. 1995, Malmstrom et al. 1997, Asner 2000). However, since these errors were poorly characterized, added errors could result from conversions of NDVI values to biomass (Asner 2000). Due to these complications, NDVI was not converted to biomass in this analysis.

The NDVI data are from a region that is grazed. Therefore it was necessary to incorporate grazing activity in the Savanna model runs for an accurate comparison. A light grazing treatment of 14.65 animal units per year (AUY km-2) was included in simulation runs for the validation analysis to incorporate realistic grazing activity on the grasslands. Vegetation data from heav- 
ily grazed plots were compared to Savanna output data in grazing scenarios with heavy grazing.

\section{Model experiments}

The first goal of this analysis was to determine through model experiments, the stocking rates that were sustainable on the typical steppe. For the purpose of this paper, the system was defined sustainable if herbaceous plants remained the dominant vegetation and could support grazing as a form of land use. This was accomplished by modeling the effects of different stocking rates on vegetation. A stocking rate analysis is only 1 of many different types of management that could be tested, but was chosen based on the scale and type of this analysis. Fourteen different stocking rates were chosen for model runs, ranging from extremely low to extremely high rates (Table 2 ). The model

Table 2. Livestock composition of each density $\left(\mathrm{km}^{-2}\right)$ and its total animal unit per year (AUY) equivalent used in model experiments. Animal unit equivalents: $\operatorname{cow}=1$, sheep $=$ 0.14 , horse $=1.8$.

\begin{tabular}{ccccr}
\hline \hline $\begin{array}{c}\text { Stocking } \\
\text { rate }\end{array}$ & Sheep & Horse & Cow & AUY \\
\hline 1 & 5 & 1 & 3 & 5.55 \\
2 & 7 & 2 & 4 & 8.65 \\
3 & 10 & 2 & 6 & 11.10 \\
4 & 15 & 3 & 7 & 14.65 \\
5 & 20 & 4 & 8 & 18.20 \\
6 & 23 & 5 & 12 & 24.45 \\
7 & 25 & 6 & 15 & 29.55 \\
8 & 27 & 7 & 17 & 33.65 \\
9 & 30 & 8 & 20 & 38.90 \\
10 & 33 & 8 & 22 & 41.35 \\
11 & 35 & 8 & 25 & 44.65 \\
12 & 40 & 8 & 30 & 50.40 \\
13 & 43 & 9 & 32 & 54.65 \\
14 & 45 & 10 & 35 & 59.75 \\
\hline
\end{tabular}

averages stocking rate over the entire gridded area, so at any particular moment, some grid-cells could have a higher number of specified animals, whereas others could have fewer. Proportions of animals in each livestock species group were based on typical herd sizes in that region. Therefore there were proportionally more sheep than cattle, and very few horses. Population numbers of sheep, horses, and cattle were converted into AUY km-2 for analysis. Grazing intensity, otherwise known as the proportion of vegetation removed, was used to describe effects of stocking rate on vegetation. McNaughton (1979) defined grazing intensity as:

$$
\mathrm{GI}=1-(\mathrm{g} / \mathrm{u})
$$

where $\mathrm{g}=$ biomass in grazed area and $\mathrm{u}=$ biomass in ungrazed areas. Grazing intensity data were averaged for the growing season May through October for analysis.

Each model run was 50 years in length. Model output of herbaceous and shrub above ground net primary production (ANPP); grass, forb, and shrub live roots, averaged from May through October, and then averaged in 10-year increments; and percent vegetation offtake, averaged May through October, from each stocking rate were used in grazing intensity analyses to determine the effect of stocking rate on the simulated grassland. Vegetation that remains dominated by herbaceous plants while grazed exists as an herbaceous stable state system. If vegetation composition changes with grazing, to one dominated by shrubs, then the system has shifted to a different stable state.

To examine the resilience of the system, animal populations were removed from model runs to simulate grasslands recovering from grazing. State variable outputs from each stocking rate run were saved and used to initialize a set of "resilience" runs to examine if vegetation composition and production could return to an herbaceous dominated stable state. Stocking rate was set at 0 for each of the 14 resilience runs and vegetation production was modeled for 50 years following removal of grazing (Burke et al. 1995). If herbaceous vegetation does not recover, then the system was not resilient to that intensity of grazing. The same weather file was used in this analysis as the previous set of runs. Herbaceous and shrub ANPP, grass, forb, and shrub live roots were used in the resilience analysis.

\section{Results}

\section{Validation analysis}

Monthly Normalized Difference Vegetation Index (NDVI) images were compared to Savanna green vegetation biomass output for the growing season, May through October, to validate vegetation biomass model predictions. For analyses, NDVI images and Savanna output were averaged for each branch and plotted over time (Fig. 2). Accuracy in Savanna's predictions of green vegetation biomass varied depending on branch. Correlations between predictions and NDVI data ranged from $\mathrm{R}^{2}=0.34(\mathrm{P}=0.00021)$ at branch 9 to $\mathrm{R}^{2}=0.57(\mathrm{P}<0.0001)$ at branch 3 (Table 3 ).

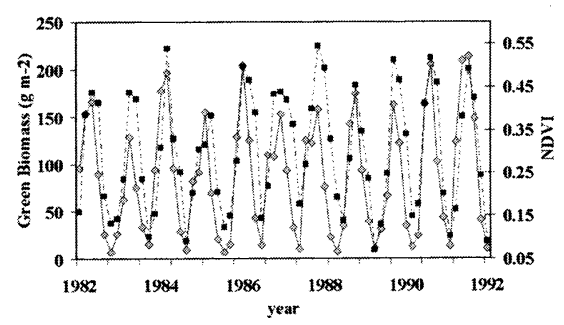

Fig. 2. Validation data of Savanna output from branch 3. Continuous line represents green biomass data $\left(\mathrm{g} \mathrm{m}^{-2}\right)$ from Savanna, dotted line represents NDVI data, rescaled to the interval -1 to 1 . Values from May to October are shown on graph.

\section{Sustainability}

Mean seasonal grazing intensity in 50 year simulations increased as stocking rate increased (Fig. 3). Animal units per year

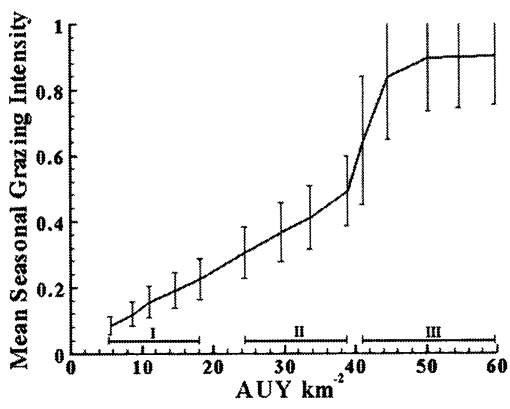

Fig. 3. Relationship between stocking rate (AUY $\left.\mathbf{k m}^{-2}\right)$ and grazing intensity $( \pm 1$ SD). Line I represents 5.6-18.2 AUY km km $^{-2}$ (light grazing), line II represents 24.5-38.9 AUY $\mathrm{km}^{-2}$ (moderate grazing), and line III represents 41.4-59.8 AUY $\mathbf{k m}^{-2}$ (heavy grazing).

(AUY) values are averaged over entire simulated area. Effects of grazing intensity on annual herbaceous above ground net primary production $\left(\mathrm{ANPP}_{h}\right)$ varied (Fig. $4)$. The $\mathrm{ANPP}_{h}$ decreased slightly as grazing intensity increased from 0.09 to 0.49 (5.6-38.9 AUY km-2, refer to Table 2). Grazing intensities 0.09 to 0.23 (5.6-18.2 AUY km$~^{-2}$ ) had the least effect on $\mathrm{ANPP}_{\mathrm{h}}$ where trends did not differ from $\mathrm{ANPP}_{h}$ with no grazing. Grazing intensities 0.30 to 0.49 (24.5-38.9 AUY km ${ }^{-2}$ ) caused a proportionally higher decrease in $\mathrm{ANPP}_{h}$ than lower grazing intensities, but still followed a similar trend as $\mathrm{ANPP}_{h}$ with no grazing. When $\mathrm{ANPP}_{\mathrm{h}}$ dropped below 100 
Table 3. Regression statistics for branches 1-12 comparing simulated biomass from May through October to 11 years of NDVI Global Area coverage $\left(4 \mathrm{~km}^{2}\right)$ data $(\mathrm{n}=65)$.

\begin{tabular}{|c|c|c|c|c|c|c|c|c|c|c|c|c|}
\hline Branch & 1 & 2 & 3 & 4 & 5 & 6 & 7 & 8 & 9 & 10 & 11 & 12 \\
\hline Area $\left(\mathrm{km}^{2}\right)$ & 196 & 334 & 323 & 212 & 301 & 130 & 655 & 208 & 609 & 412 & 141 & 79 \\
\hline Adjusted $\mathrm{R}^{2} * * *$ & 0.343 & 0.532 & 0.574 & 0.385 & 0.410 & 0.560 & 0.467 & 0.397 & 0.340 & 0.431 & 0.429 & 0.543 \\
\hline Standard Error & 0.082 & 0.090 & 0.090 & 0.092 & 0.086 & 0.091 & 0.092 & 0.081 & 0.081 & 0.082 & 0.090 & 0.078 \\
\hline
\end{tabular}

$* * *$ Significant at the 0.001 level.

$\mathrm{g} \mathrm{m}^{-2}$ year $^{-1}$ with grazing intensity 0.49 , annual shrub above ground net primary production $\left(\mathrm{ANPP}_{\mathrm{S}}\right)$ increased to $\sim 65 \mathrm{~g}$ $\mathrm{m}^{-2}$ year ${ }^{-1}$ as compared to $18.5 \mathrm{~g} \mathrm{~m}^{-2}$ year $^{-1}$ at low grazing intensities (Fig. 5). This grazing intensity did not suppress herbaceous biomass to the point that shrubs were able to gain a competitive advantage.

A grazing intensity of 0.64 and higher (41.4-59.8 AUY km$~^{-2}$ ) on herbaceous vegetation was not sustainable and caused a sharp decline in $\mathrm{ANPP}_{h}$ subsequently followed by an increase in $\mathrm{ANPP}_{\mathrm{S}}$ (Fig. 5). After 43 years of grazing with intensity $0.64, \mathrm{ANPP}_{\mathrm{h}}$ dropped to an average of 10 $\mathrm{g} \mathrm{m}^{-2}$ year $^{-1}$ and the system shifted to a shrub dominated state (Fig. 4). This shift was reached more rapidly with higher grazing intensities, where $\mathrm{ANPP}_{h}$ was reduced to an average of $9.0 \mathrm{~g} \mathrm{~m}^{-2}$ year $^{-1}$ after 18 years with intensity 0.84 and after 11 years with intensity $0.89-0.90$. This switch from grass-dominated vegetation to shrub-dominated vegetation demonstrates a key state change with the new system being inferior for livestock that graze herbaceous plants. There was a rapid replacement of the herbaceous community by a shrub-dominated one due to shrub's access to water in deep soil layers and lack of browsing on shrub vegetation in this simulation.

Biomass output data from grazing intensity 0.64 was compared to field data (Christensen et al. 1998) to check model accuracy in a heavy grazing simulation. Heavily grazed areas were randomly chosen within a $2 \mathrm{~km}$ radius of herder's households. Herbaceous biomass collected in the field during the month of August 1997 ranged from $26.5 \mathrm{~g} \mathrm{~m}^{-2}$ to $98.1 \mathrm{~g} \mathrm{~m}^{-2}$ in heavily grazed plots, with an average of $63.85 \mathrm{~g} \mathrm{~m}^{-2}$. These values closely matched modeled herbaceous biomass data $(45.2 \mathrm{~g}$ $\mathrm{m}^{-2}$ ) from areas grazed with intensity 0.64 , during August of the same year.

Grass root biomass ranged from $328.0 \mathrm{~g}$ $\mathrm{m}^{-2}$ to $476.0 \mathrm{~g} \mathrm{~m}^{-2}$ with grazing intensities 0.09 to 0.49 , but contrary to ANPP, root biomass increased as grazing intensity increased with grazing intensities 0.090.23 (Fig. 6). Herbaceous live root biomass decreased as grazing intensity increased from 0.30 to 0.49 , averaging a
$24 \mathrm{~g} \mathrm{~m}^{-2}$ decrease with each intensity increment of 5 AUY km$~^{-2}$. Although root biomass decreased, their dynamics followed the same trend as roots with lighter grazing intensities. Grazing intensities of 0.49 and higher resulted in a sharp decline of grass root biomass.

Shrub root biomass with grazing intensities 0.09 to 0.49 remained stable, between
$12.9 \mathrm{~g} \mathrm{~m}^{-2}$ and $19.8 \mathrm{~g} \mathrm{~m}^{-2}$ (Fig. 7). Biomass values are low because model output expresses shrubs as $g$ per total area in the steppe. Shrubs cover only 12 percent of the total area in the typical steppe vegetation, therefore reported shrub biomass is lower than data, which is expressed in terms of grams per meter squared of shrub-patches. Shrub root biomass in areas grazed with

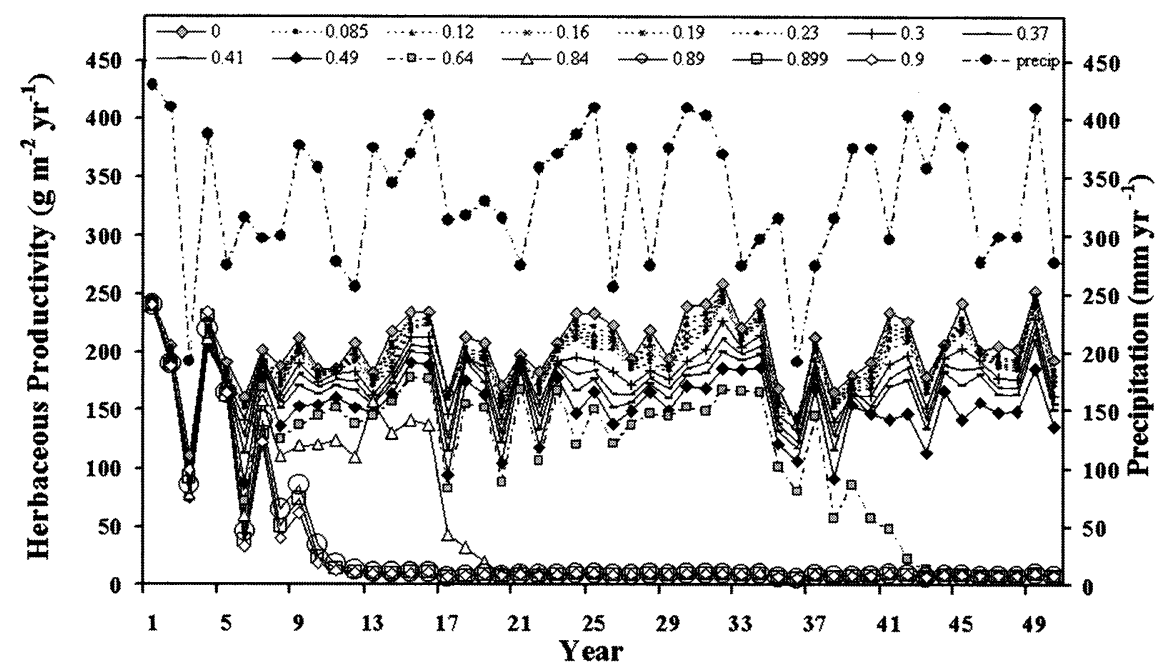

Fig. 4. Annual herbaceous ANPP from 50-year simulation runs with no grazing (0) and 14 different grazing intensities (5.6- $59.8 \mathrm{AUY} \mathbf{~ m}^{-2}$ ) and annual precipitation data.

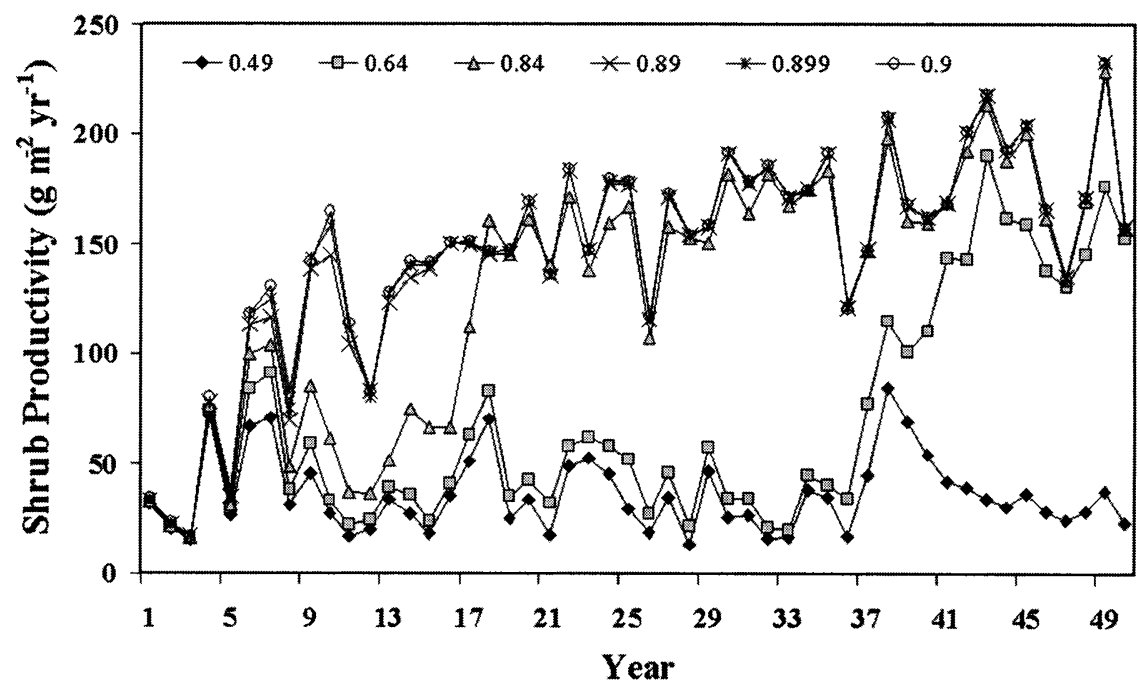

Fig. 5. Annual shrub ANPP in areas grazed with intensities of 0.49 to 0.9 (38.9 to 59.8 AUY $\left.\mathbf{k m}^{-2}\right)$. 


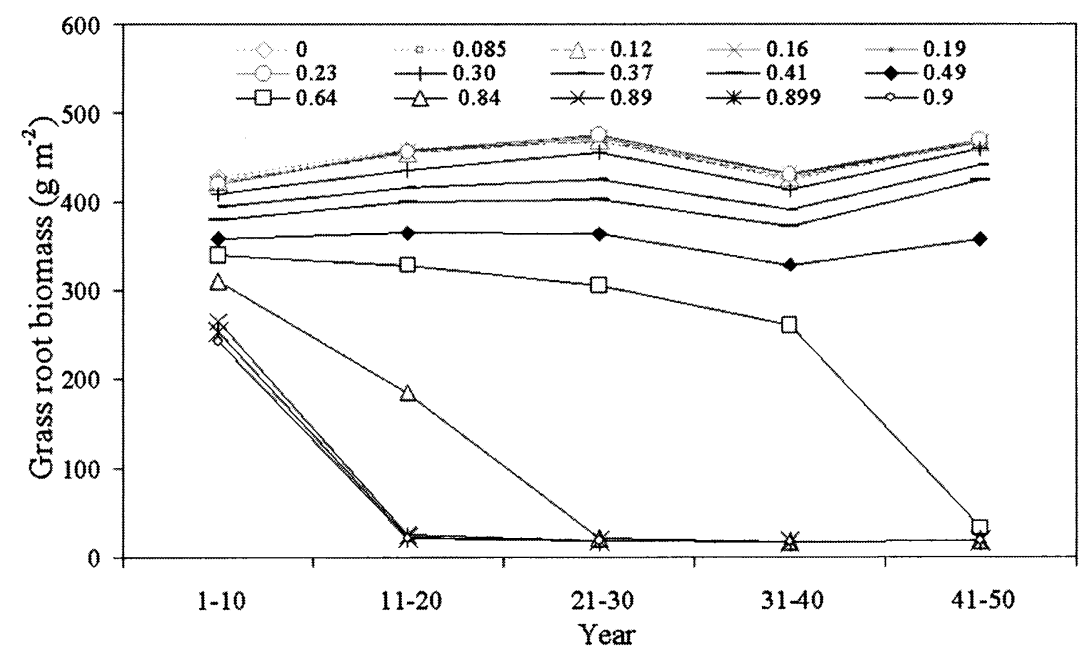

Fig. 6. Root dynamics from grass vegetation $\left(\mathrm{g} \mathrm{m}^{-2}\right)$ averaged for the growing season May through October, then averaged in 10-year increments. Each line represents different grazing intensities (stocking rates 1-14).

intensity 0.64 and higher gained a competitive advantage over herbaceous root biomass and increased to levels ranging from $179.8 \mathrm{~g} \mathrm{~m}^{-2}$ to $238.7 \mathrm{~g} \mathrm{~m}^{-2}$.

Based on results from Savanna output, grazing intensities were categorized into 3 groups: light, moderate, and heavy (Fig. 3 ). A light grazing intensity included grazing intensities of $0.09-0.23$ (the 5 lowest stocking rates of 5.6-18.2 AUY km-2). Light grazing intensity did not have a large effect on root biomass dynamics as annual average root biomass slightly increased as grazing intensities increased from 0.09 to 0.23 (Figs. 6 and 7). There was a slight decrease in $\mathrm{ANPP}_{h}$ as grazing intensity increased, but $\mathrm{ANPP}_{\mathrm{h}}$ under light grazing intensity followed closely the trend of $\mathrm{ANPP}_{\mathrm{h}}$ without grazing. Moderate grazing occurred at grazing intensities of 0.30 to 0.49 (24.5-38.9 AUY $\mathrm{km}^{-2}$ ), a range where the herbaceous system was sustained. Averaged annual root biomass decreased as grazing intensity increased within the moderate intensity category. Heavy grazing occurred at grazing intensities above 0.49 , and herbaceous production was not sustainable at these levels (the five highest grazing rates of 41.4-59.8 AUY km²).

Thresholds in herbaceous production, or point where higher grazing intensities result in a shift to a shrub dominated system, occurred with heavy grazing only when there were repeated years with below average precipitation and herbaceous production dropped below $70 \mathrm{~g} \mathrm{~km}^{-2}$ $\mathrm{yr}$ and root biomass fell below $200 \mathrm{~g} \mathrm{~m}^{-2}$ (Figs. 4 and 6). Average annual precipita- year had above average precipitation and $\mathrm{ANPP}_{h}$ recovered. Starting with the $17^{\text {th }}$ year, there were 3 consecutive years with below average precipitation and $\mathrm{ANPP}_{h}$ dropped to $43 \mathrm{~g} \mathrm{~m}^{-2}$ year ${ }^{-1}$. This grazing intensity passed the threshold of $70 \mathrm{~g} \mathrm{~m}^{-2}$ year $^{-1}$ in $\mathrm{ANPP}_{\mathrm{h}}$ and $200 \mathrm{~g} \mathrm{~m}^{-2}$ in grass biomass, and shrubs became dominant. The drop in $\mathrm{ANPP}_{h}$ with grazing intensity 0.64 occurred after simulation years 36-38, all of which had below average annual precipitation $(192.5 \mathrm{~mm}, 274.3$ $\mathrm{mm}$, and $315.6 \mathrm{~mm}$ respectively). While herbaceous vegetation was dominant and grazing intensity was light, shrub production remained low. When herbaceous vegetation was removed by heavy grazing intensity, which coincided with low precipitation years, the threshold was passed and shrub production increased to maximum values.

\section{Resilience}

Results from simulation runs that examined resilience of the system were similar to results from sustainability runs. The herbaceous above ground net primary production $\left(\mathrm{ANPP}_{h}\right)$ in areas previously grazed with intensities 0.085 to 0.49 (5.638.9 animal units per year (AUY) $\mathrm{km}^{-2}$ ) returned to levels similar to runs with no grazing. The ANPPh associated with a grazing intensity of 0.49 took 46 years to recover to the same biomass levels as with no grazing, but the reduction in $\mathrm{ANPP}_{h}$ was small, therefore the system was resilient with this grazing intensity. The $\mathrm{ANPP}_{h}$ that was grazed with intensities 0.64 to 0.9 was unable to recover, and

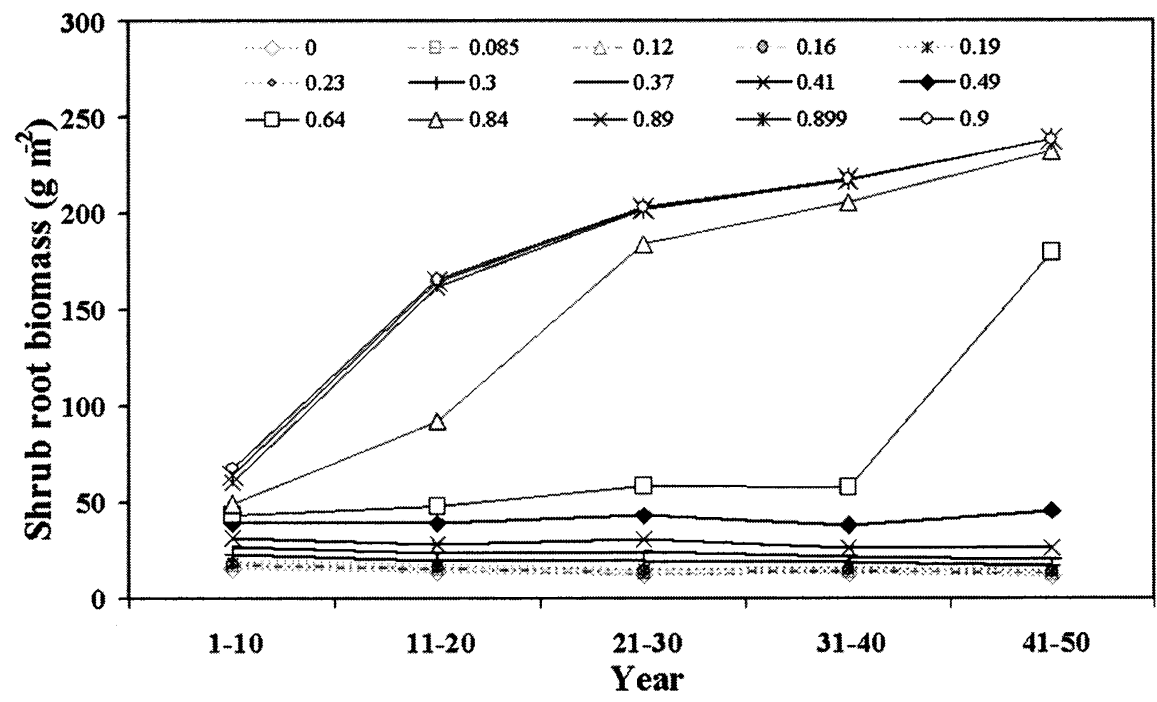

Fig. 7. Shrub root dynamics from grass vegetation $\left(\mathrm{g} \mathrm{m}^{-2}\right)$ averaged for the growing season May through October, then averaged in 10-year increments. Each line represents different grazing intensities (stocking rates 1-14). 
shrub above ground net primary production $\left(\mathrm{ANPP}_{\mathrm{S}}\right)$ remained high. Herbaceous vegetation grazed with intensity 0.64 slightly increased $\mathrm{ANPP}_{\mathrm{h}}$ to $32.5 \mathrm{~g} \mathrm{~m}^{-2}$, but was unable to compete with shrubs and did not return to the original biomass level.

Root biomass from simulation runs examining resilience of the system was analyzed in a similar fashion as sustainability runs. Grass root biomass ranged from $405 \mathrm{~g} \mathrm{~m}^{-2}$ to $467 \mathrm{~g} \mathrm{~m}^{-2}$ in runs that had previously been grazed with intensities 0.085 to 0.49 . Grass root biomass decreased as grazing intensity increased from 0.085 to 0.49 and followed a trend similar to grass root biomass with no grazing. Shrub root biomass was not affected by the removal of grazing. Shrub root biomass in areas that had been grazed with intensities 0.085 to 0.49 remained stable, while in areas previously grazed with intensity 0.64 to 0.9 , shrub root biomass ranged from $201.9 \mathrm{~g} \mathrm{~m}^{-2}$ to $253.7 \mathrm{~g} \mathrm{~m}^{-2}$. Shrub root biomass maintained the competitive advantage over grass root biomass in areas that had grazing intensities of 0.64 and higher for 50 years after grazing was removed.

\section{Discussion}

Ecosystems that are grazed are subject to change due to shifts in human and livestock population levels, changes in climate, changes in land use from grazing to agriculture, alteration of management technologies, and changes in management such as the change from nomadic to sedentary grazing practices (Archer et al. 1995, Walker and Abel 1999). Management changes have occurred in the Inner Mongolia region without an understanding of their consequences and therefore have left the system vulnerable to change, and the arid climate of this region makes the system more likely to exhibit vegetation state changes under grazing (Ellis and Swift 1988). Despite the aridity of the system, present day herders maintain a style of management where livestock numbers are kept constant or gradually increased, despite varying weather patterns (Bilik 1996, Williams 1996b). As a result of these increases, grassland degradation is increasing (Li 1989, Sheehy 1993, Chen 1996) and the number of livestock die-offs is increasing (Chen 1996). Heavy grazing during low precipitation years may bring this system to a threshold beyond which there can be a shift to an alternate stable state (Holling 1973, Sheehy 1993), and grazing should be managed with this in mind (Ellis and Swift 1988, Ellis et al. 1993). It is vital to recognize these thresholds in order to devise sustainable management regimes (Cowling 2000).

Westoby et al. (1989) proposed the State-and Transition model for range management. This model recognizes the dynamics of rangelands by describing different vegetation states, and the importance of understanding the mechanisms causing transitions among states. 'Transitions' occur when thresholds in a particular stable state are passed and the system shifts to an alternate stable state. Grazed landscapes are vulnerable to shifts between stable states when subject to poor management or the combination of intensified grazing pressure and extreme climate events (Friedel 1991, Laycock 1991, Ellis et al. 1993, Rietkerk and van de Koppel 1997). For these reasons, a systems approach was used to more specifically address the problems of grazing management at a particular site. From modeling results, this system was hypoth- esized as having the potential to switch from a grass to a shrub dominated stable state when heavy grazing is combined with below average precipitation events. In model simulations above a certain grazing intensity, herbaceous plants could not recover from grazing removals and shrubs were able to capitalize on available resources once the herbaceous vegetation was suppressed (Archer 1995). Because shrubs were not browsed they displaced the overgrazed herbaceous plants and became the dominant functional group.

The Savanna model determined what combinations of grazing intensities, precipitation, and vegetation patterns were sustainable for the Xilingol region and found where thresholds and stable states exist. Results of the model analysis helped to explain how heavy grazing intensities, above 0.49 , in combination with 2 or more years of below average precipitation events surpassed the threshold of sustainability and caused a sharp decline in grass vegetation. Angell (1997) conducted a 4year study in the Northern Great Basin

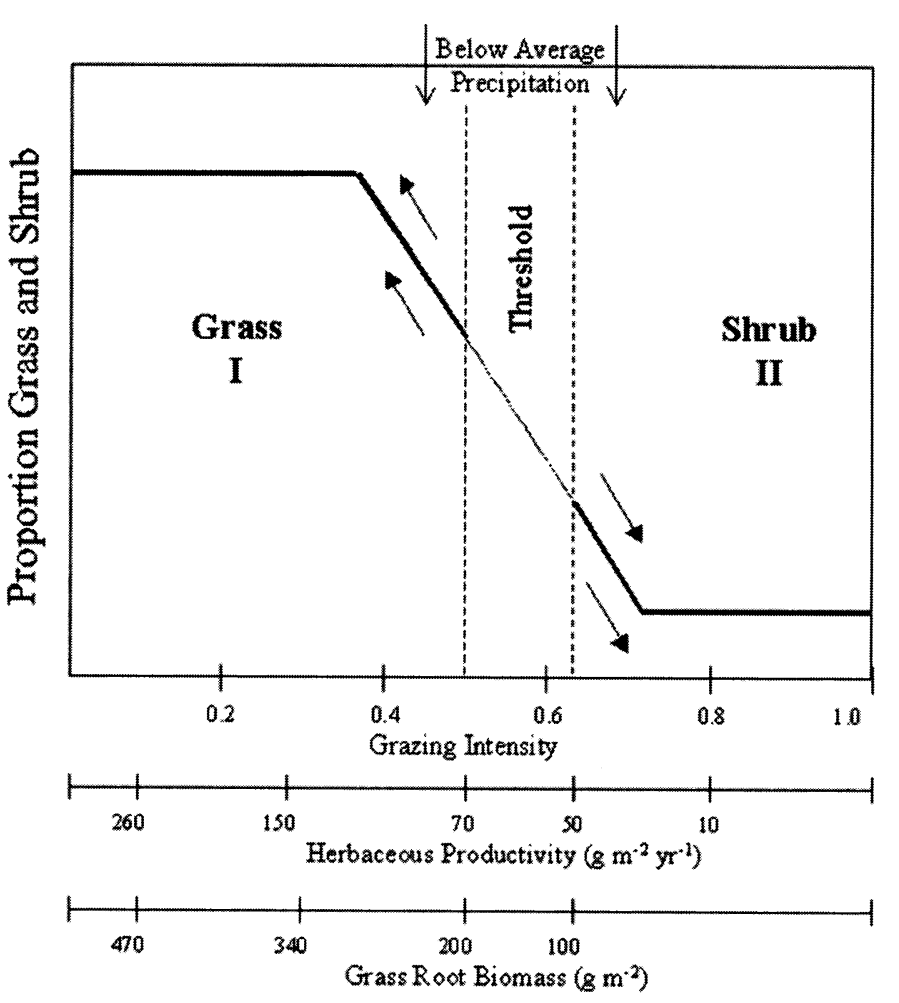

Fig. 8. Grass/shrub stable state system, one dominated by grass (region I) and the other shrubs (region II). Horizontal lines (above Grass and below Shrub) represent systems in a stable state. As grazing intensity (GI) increases, the system increases in shrubby biomass (horizontal line shifts diagonally). The system is resilient if grazing intensity is below threshold zone (GI 0.49-0.63) and will return to a grass stable state if grazing is removed (arrows) despite precipitation being below average. If GI is higher than threshold zone (GI $>0.63$ ) and precipitation is below average, the grassland system is not resilient to grazing and will gradually move towards a shrub stable state (arrows). The higher the GI, the shorter amount of time it takes for the system to move towards a shrub stable state. 
Experimental Range, Oregon, on the effects of grazing on grass and shrub vegetation. His results were similar to this study in that grass standing crop decreased in years 2,3 , and 4 with heavy grazing, and low precipitation events limited grass regrowth after grazing. Standing biomass in heavily grazed sites (1.2 animal units (AU) ha $^{-1}$ ) was reduced by $43 \%$ as compared to continuously grazed (0.6 $\left.\mathrm{AU} \mathrm{ha}{ }^{-1}\right)$ sites. He also found an increase in juvenile sagebrush survival due to heavy grazing on herbaceous vegetation. Gillen et al. (1998) also found decreases in standing crop due to heavy as compared to light grazing, decreasing by as much as $50 \%$ during 1 growing season. Although these were short-term studies, they show a similar trend to the first 10 years of model simulations in this analysis.

Field data from the Inner Mongolian Grassland Ecosystem Research Station (Christensen et al. 1998) in the high-stocking rate areas did not show an increase in shrubs as predicted by the model. Possible explanations are that the fieldwork was conducted in 1 season, while the increase in shrubs in the modeling experiments occurred over a 38-year period. Also, livestock numbers have only recently increased at the Baiinxile farm, whereas the modeling results are predictions of what could happen after many years of heavy grazing. Soil information was limited at the scale used, which could potentially affect shrub growth and/or effects of grazing on shrub growth (Rietkerk and van de Koppel 1997, van de Koppel et al. 1997). There is uncertainty in how fast shrubs in this region can spread, based on seed production and establishment rates, which could also affect responses to grazing (Archer 1995).

Model simulations included only grazers because sheep, horses, and cattle dominate the current system in Inner Mongolia. If goats, which browse shrubs, were simulated, then results from model simulations would likely be different. In neighboring Mongolia, increases in shrubs are not seen with heavy grazing (Fernandez-Gimenez and Allen-Diaz 1999, Fernandez-Gimenez 2000), possibly because goats, which consume shrubs, are a major component of livestock herds in that region. Fire does not occur naturally in this area, but it could suppress shrubby encroachment (Ellison 1960, Archer 1995, Scholes and Archer 1997) and could potentially suppress the competitive advancement of shrubs with heavy grazing in model scenarios.

A graphical representation of the dynamics of the system in regard to thresholds and stable states describes 2 steady state systems divided by a threshold zone where section I is dominated by grass vegetation and section II is dominated by shrubby vegetation (Fig. 8 ). The angled line between the 2 stable-state regions represents a transitional system. As grazing intensity increases towards the threshold isocline (grazing intensity = 0.49 , herbaceous productivity $=70 \mathrm{~g} \mathrm{~m}^{-2}$ year ${ }^{-1}$, root biomass $=200 \mathrm{~g} \mathrm{~m}^{-2}$ ) the proportion of shrubs increases. But when grazing is removed, the system is resilient to these levels of grazing and is capable of returning to a grass steady state (represented by arrows) despite precipitation being below average. If grazing intensity increases above a threshold value (grazing intensity $=0.49-0.64$, herbaceous productivity $<70 \mathrm{~g} \mathrm{~m}^{-2}$ year $^{-1}$, and root biomass $<$ $200 \mathrm{~g} \mathrm{~m}^{-2}$ ) the system shifts to a shrub dominated stable-state (region II). When grazing intensity ranges from 0.64 to 0.89 during below average precipitation events, the grassland system is not resilient. These levels of grazing will eventually result in a shrub dominated system, represented by the vertical line in region II.

The Savanna model experiments identified potential grazing thresholds in this system, providing better understanding of sustainability and resilience for future successful management. Understanding thresholds in grazing systems has important policy implications in the Inner Mongolian region. Because of the highly variable climate pattern, it is important not to overstock grazing areas and/or to maintain grazing reserves for use during periods of climate stress (Cowling 2000). This simulation analysis as well as other research has shown the negative impact of high grazing intensities. To avoid negative impacts on this grassland region, policymakers must limit the amount of livestock or limit high levels of grazing intensity in certain areas to maintain sustainable livestock production.

\section{Literature Cited}

Agren, G.I., R.E. McMurtrie, W.J. Parton, J. Pastor, and H.H. Shugart. 1991. Stateof-the-art of models of production-decomposition linkages in conifer and grassland ecosystems. Ecol. Appl. 1:118-138.

Angell, R.F. 1997. Crested wheatgrass and shrub response to continuous or rotational grazing. J. Range Manage. 50:160-164.

Archer, S., D.S. Schimel, and E.A. Holland. 1995. Mechanisms of shrubland expansion: land use, climate, or $\mathrm{CO}_{2}$ ? Clim. Change 29:91-99.
Archer, S. 1995. Herbivore mediation of grasswoody plant interactions. Tropical Grassl.. 29:218-235.

Asner, G. P. 2000. A biogeophysical approach for automated SWIR unmixing of soils and vegetation. Remote Sens. Environ. 74:99-112.

Ball, J. T. 1988. An analysis of stomatal conductance. Ph.D. Thesis, Stanford Univ. Stanford, Calif.

Bilik, N. 1996. Culture, the environment and development in Inner Mongolia. p. 134-146. In: C. Humphrey and D. Sneath, (eds.), Culture and Environment in Inner Asia. White Horse Press, Cambridge.

Boone, R.B., M.B. Coughenour, K.A. Galvin, and J.E. Ellis. 2002. Addressing management questions for Ngorongoro Conservation Area. Afr. J. Ecol. 40:128-150.

Burke, I.C., W.K. Lauenroth, and D.P. Coffin. 1995. Soil organic matter recovery in semiarid grasslands: implications for the conservation reserve program. Ecol. Appl. 5:793-801.

Caughley, G., J. Short, G.C. Grigg, and H. Nix. 1987. Kangaroos and climate: an analysis of distribution. J. Anim. Ecol. 56:751-761.

Chen, S. 1996. Inner Asian grassland degradation and plant transformation. p. 111-123. In: C. Humphrey and D. Sneath, (eds.), Culture and Environment in Inner Asia. White Horse Press, Cambridge.

Chen, Z., and X. Xiao. 1993. Degradation and restoration of natural grassland ecosystems in Inner Mongolia, China. Proc. from Grassland Ecosystem of the Mongolian Steppe: A Research Conference. Racine, Wisc.

Christensen, L., M. Coughenour, J. Ellis, L. Li, and Y. Han. 1998. Grazing effects on the typical steppe grassland of Inner Mongolia. Proceedings of the LUTEA Conference. Beijing, China.

Christensen, L., M. Coughenour, J. Ellis, L. $\mathrm{Li}$, and K. Price. 1999. An integrated Assessment of Land Use and Vegetation on the Grasslands of Inner Mongolia. Proceedings of the International Rangeland Congress, Townsville, Aust.

Coughenour, M.B. 1993. Savanna- Landscape and Regional Ecosystem Model. Natur. Resource Ecol. Lab. Colorado State University, Ft. Collins, Colo.

Coughenour, M.B. and F.J. Singer. 1996a. Yellowstone elk population responses to fire - a comparison of landscape capacity and spatial-dynamic ecosystem modeling approaches. p. 169-180. In: J. Greenlee, (ed.), The ecological implications of fire in Greater Yellowstone: Proceedings of the Second Biennial Conference on the Greater Yellowstone Ecosystem. International Association of Wildland Fire, Fairfield, Wash.

Coughenour, M. B. and F. J. Singer. 1996b. Elk population processes in Yellowstone National Park under the policy of natural regulation. Ecol. Appl. 6:573-593. 
Cowling, R. M. 2000. Challenges to the 'new' rangeland science. TREE 15:303-304.

Ellis, J.E. and D.M. Swift. 1988. Stability of African pastoral ecosystems: alternate paradigms and implications for development. J. Range Manage. 41:450-459.

Ellis, J.E., M.B. Coughenour, and D.M. Swift. 1993. Climate variability, ecosystem stability and the implications for range and livestock development. p. 31-41. In: R. Behnke, I. Scoones, and C. Kerven, (eds.), Range Ecology at Disequilibrium. ODI, London.

Ellison, L. 1960. Influence of grazing on plant succession of rangelands. The Bot. Rev. 26:1-78.

FAO. 1991. World Soil Resources. Soils Bull. 66. FAO, Rome.

Fernandez-Gimenez, M.E. 2000. The role of Mongolian nomadic pastoralists' ecological knowledge in rangeland management. Ecol. Appl. 10:1318-1326.

Fernandez-Gimenez, M.E. and B. AllenDiaz. 1999. Testing a non-equilibrium model of rangeland vegetation dynamics in Mongolia. J. Appl. Ecol. 36:871-885.

Friedel, M. H. 1991. Range condition assessment and the concept of thresholds: a viewpoint. J. Range Manage. 44:422-426.

Gillen, R.L., F.T. McCollum III, K.W. Tate, and M.E. Hodges. 1998. Tallgrass prairie response to grazing system and stocking rate. J. Range Manage. 51:139-146.

Gunderson, L. H. 2000. Ecological resilience in theory and application. Annu. Rev. Ecol. Syst. 31:425-439.

Hall, C.A.S. and J.W.J. Day. 1997. Systems and models; terms and basic principles. p. 5-36. In: C. A. S. Hall and J. W. Day, (eds.), Ecosystem Modeling in Theory and Practice: An Introduction with Case Histories. John Wiley \& Sons, New York, N.Y.

Holling, C. S. 1973. Resilience and stability of ecological systems. Annu. Rev. Ecol. Systems 4:1-24.

IDRISI. 1997. The IDRISI Project, Clarks Lab. Worcester, Mass.

Jiangou, W. and O. Loucks. 1992. Xilingele. p 67-84. In: Grasslands and Grassland Science in Northern China. A report of the Committee on Scholarly Communication with the People's Republic of China. National Academy Press. Washington D.C.

Jorgensen, S.E. 1994. Fundamentals of ecological modelling. Elsevier, N.Y.

Justice, C.O., J.R.G. Townshend, B.N. Holben, and C.J. Tucker. 1985. Analysis of the phenology of global vegetation using meteorological satellite data. Int. J. Remote Sensing 6:1271-1318.

Kiker, G.A. 1998. Development and comparison of savanna ecosystem models to explore the concept of carrying capacity. Ph.D. Thesis, Cornell University, Ithica, N.Y.

Lavrenko, E.M. and Z.V. Karamysheva. 1993. Steppes of the former Soviet Union and Mongolia. p. 3-59. In: R. T. Coupland, (ed.), Ecosystems of the World. Natural Grasslands: Eastern Hemisphere and Resume. Elsevier, N.Y.
Laycock, W. A. 1991. Stable states and thresholds of range condition on North American rangelands: A viewpoint. J. Range Manage. 44:427-433.

Lele, S. and R.B. Norgaard. 1996. Sustainability and the scientist's burden. Cons. Biol. 10:354-365.

Li, J. D. 1978. Aneurolepidium chinense grassland in China. J. Northeast Normal Univ. 1:145-159.

Li, Y.H. 1989. Impact of grazing on Aneurolepidium chinense steppe and Stipa grandis steppe. Oecologica Appl. 10:31-46.

Lubchenco, J., A.M. Olson, L.B. Brubaker, S.R. Carpenter, M.M. Holland, S.P. Hubbell, S.A. Levin, J.A. MacMahon, P.A. Matson, J.M. Melillo, H.A. Mooney, C.H. Peterson, H.R. Pulliam, L.A. Real, P.J. Regal, and P.G. Risser. 1991. The sustainable biosphere initiative: an ecological research agenda. Ecol. 72:371-412.

Malingreau, J.P. 1986. Global vegetation dynamics: satellite observations over Asia. Int. J. Remote Sensing 7:1121-1146.

Malmstrom, C.M., M.V. Thompson, G.P. Juday, S.O. Los, JT. Randerson, and C.B. Field. 1997. Interannual variation in globalscale net primary production: testing model estimates. Global Biogeochem. Cycles 11:367-392.

McNaughton, S.J. 1979. Grazing as an optimization process: grass-ungulate relationships in the Serengeti. The Amer. Nat. 113:691-703.

National Research Council. 1992. Grasslands and Grassland Sciences in Northern China. National Academy Press, Washington D.C.

Noy-Meir, I. 1975. Stability of grazing systems: an application of predator-prey graphs. J. Ecol. 63:459-481.

Privette, C. F., G. A. Wick, D. Baldwin, and W. J. Emery. 1995. Effects of orbital drift on Advanced Very High Resolution Radiometer products: normalized difference vegetation index and sea surface temperature. Remote Sens. Environ. 53:164-171.

Renzhong, W. and E.A. Ripley. 1997. Effects of grazing on a Leymus chinensis grassland on the Songnen plain of north-eastern China. J. Arid Environ. 36:307-318.

Rietkerk, M. and J. van de Koppel. 1997. Alternate stable states and threshold effects in semi-arid grazing systems. OIKOS 79:69-76.

Scholes, R. J. and S. R. Archer. 1997. Treegrass interactions in savannas. Annu. Rev. Ecol. Syst. 28:517-544.

Sheehy, D. P. 1993. Grazing management strategies as a factor influencing ecological stability of Mongolian grasslands. Nomadic Peoples 33:17-30.

Sneath, D. 1998. State policy and pasture degradation in Inner Asia. Sci. 28:1147-1148.

Tucker, C. J. 1979. Red and photographic infrared linear combinations for monitoring vegetation. Remote Sens. Environ. $8: 127-150$.
Tucker, C.J., J.R.G. Townshend, and T.E. Goff. 1985. African land-cover classification using satellite data. Science 227:369-375.

van de Koppel, J., M. Rietkerk, R. J. Weissing. 1997. Catastrophic vegetation shifts and soil degradation in terrestrial grazing systems. TREE. 12:352-256.

Walker, B. and N. Abel. 1999. Resilient rangelands- adaptation in complex systems. Workshop on "Resilience of Rangelands". The Resilience Network. CSIRO. Canberra, Aust.

Weisberg, P. J. 2000. Model-based assessment of aspen responses to elk herbivory in Rocky Mountain National Park. Report to Rocky Mountain Nat. Park, from the Nat. Resource Ecol. Lab., Colorado State Univ., Fort Collins, Colo., USA.

Westoby, M., B. Walker, and I. Noy-Meir. 1989. Opportunistic management for rangelands not at equilibrium. J. Range Manage. 42:266-274.

Williams, D. M. 1996a. The barbed walls of China: a contemporary grassland drama. The J. Asian Studies 55:665-691.

Williams, D. M. 1996b. Grassland Enclosures: Catalyst of land degradation in Inner Mongolia. Human Organization 55:307-313.

Xiao, X., D.S. Ojima, and C.A. Ennis. 1997. Land cover classification of the Xilin River Basin, Inner Mongolia, using Landsat TM imagery. Res. on Grassl. Ecosys. 5:240-252.

Xiao, X., J. Shu, W. Yifeng, D. S. Ojima, and C. D. Bonham. 1996. Temporal variation in above ground biomass of Leymus chinense steppe from species to community levels in the Xilin River Basin, Inner Mongolia, China. Vegetatio 123:1-12.

Yang, H. 1987. Proceedings of the International Symposium on Grassland Vegetation. Hohhot, China.

Zhu, T. C. 1993. Grasslands of China. p. 61-82. In: R. T. Coupland, (ed.), Ecosystems of the World. Natural Grasslands: Eastern Hemisphere and Resume. Elsevier, N.Y. 